\title{
Editorial
}

\section{Sustainable development and the role of African scientific research centres}

\author{
Anour Dafaalla ${ }^{1}$, Suad Badri², Mohammed Khalil Saeed ${ }^{3}$, Mohamed Alhaj ${ }^{* 1}$ \\ ${ }^{1}$ The Sudanese Researchers Foundation, Khartoum, Sudan \\ ${ }^{2}$ School of Rural Extension, Education, and Development, Ahfad University for Women, Omdurman, Sudan \\ ${ }^{3}$ Department of Radiological Sciences, Applied Medical Sciences College, Najran University, \\ Najran, 1966, Saudi Arabia
}

*Corresponding author E-mail: ajet@sresearchers.org

Scientific research in the engineering and technology domains plays a centric role in realizing sustainable development in Africa. In particular, a multidisciplinary research (and sometimes even crossdisciplinary) approach is required when tackling Africa's complex challenges such as poverty, climate change, energy access, water resources management, energy-water-food nexus, sustainable urban environment, cybersecurity, and others. To advance this research, African researchers should be empowered to conduct high-quality research and communicate their findings and recommendations to all stakeholders in open-access platforms. Building on the above, the Sudanese Researchers Foundation (SRF) is proud to announce the launch of the African Journal of Engineering \& Technology (AJET); our inaugural open-access peer-reviewed journal focusing on engineering, technology, and sustainable development.

AJET is an open-access, peer-reviewed, and multidisciplinary journal that aims to serve as a platform for researchers, professionals, and policy-makers from a variety of backgrounds to discuss and disseminate applied research in engineering and technology that addresses Africa's sustainable development. AJET welcomes submissions in all domains of engineering and technology, including the policy and economic implications of engineering and technology research. AJET will help boost the efforts of publishing original research from Africa, and hence, change the status-quo of a weak contribution to the global scientific output. AJET is published by the Sudanese Researchers Foundation (SRF) and powered by ScienceOpen.

The SRF is a scientific, voluntary, non-governmental and non-for-profit organization that aims to create a common platform for interaction between Sudanese learners and researchers to. Founded in 2009, the SRF has expanded rapidly until it became the largest digital platform in social media networks for Sudanese researchers and students with over than half a million members. The SRF's values are integrity, freedom, quality, curiosity and innovation. The SRF launched AJET building on its mission to establish and advance the momentum of research and education in Sudan and Africa as a whole. The SRF operates 
through decentralized leadership and management models that allow hundreds and thousands of volunteers to collaborate in different projects. One of which is the African Journal of Engineering \& Technology, which is natural's heaven for its members' scientific output as we aspire to become one of the leading International publishers.

In addition to AJET's role in advancing scientific publishing, the journal will also support African scientific institutions. Scientific research institutions represent an advanced industry in thinking, creativity and scientific measurement of general trends. The creation of these centers in Africa provides an important means for the development of human knowledge as it achieves sustainable development and knowledge differentiation in economic, social and other fields. It also generates creativity and innovation which achieves the partnership with its financial and human aspects to serve society and solve its problems and enrich knowledge in its various forms.

The role of research centers in Africa will contribute to policy formulation at regional and global levels by providing a link between scientists and decision makers and helping to disseminate relevant information in an easily understandable form [1]. The urgent need in terms of the growing role of knowledge and creativity in the world of work and the economy doubles the importance of these centers to meet the stage and keep pace with major changes in knowledge, technology, work trends and markets.

The role of Sudanese Researchers Foundation, as well as other research institutions in Africa, in achieving sustainable development depends on many standards it seeks to achieve. In general, the quality of the research center's leadership and the extent of its commitment is one of the most important of these standards. These include effective management of the research center's tasks and programs, mobilization of financial and human resources, quality control and independence. Besides that, the ability to mobilize a highly qualified group of experienced and productive researchers and analysts who are recognized as emerging or former experts in their research fields. Moreover, the ability to produce high-quality research for targeted policies and make it available to decision makers is an important criterion for these research institutions. Many other standards that ensure the quality of the outputs of these research centers include the academic rigor associated with completed research, demonstrated commitment to the production of independent research and analysis, the ability to reach out to and communicate with basic institutions, target audiences, and key individuals similar to government officials, civil society, traditional and new media, and academic institutions, and the effective use of research summaries and reports [2]. AJET will play an active role in supporting and advancing these standards.

Moreover, AJET will contribute to the on-going research efforts focusing on sustainable development and innovation. Enabling change through innovative research, from a traditional disciplinary view to a synergistic and multidisciplinary view, requires looking beyond disciplinary needs and working towards cultivating technical integration. In particular, when considering the challenges inherent in the Global Sustainable Development Goals (SDGs) framework; notably in Africa, multidisciplinary research emerges as game-changer. Despite the widespread adoption of and progress toward SDGs, Africa continues to lag behind most of the world. The roadmap for that change needs to address several topics such as energy

2 https://doi.org/10.47959/AJET.2021.1.1.1

(C) 2021 The Authors. Published by SRF. This is an open access article under the CC BY license (http://creativecommons.org/licenses/by/4.0/). 
sustainability, water resources, food production and agriculture, manufacturing and mining, materials science and engineering, and information.

On behalf of the SRF and AJET's editorial board, we would like to seize this opportunity to extend a kind invitation to all authors, who are actively involved in engineering research supporting Africa and developing countries, to submit their papers for publication in our inaugural issue. We strongly believe that the path to sustainable development begins with sound scientific research, so let's get started!

\section{References}

[1] Grimm S, Senz S, Grimm S. The Interface between Research and Policy-Making in South Africa Exploring the institutional framework and practice of an uneasy relationship. 2018. DOI:10.23661/dp19.2018

[2] McGann, James G., "2020 Global Go To Think Tank Index Report" (2021). TTCSP Global Go To Think Tank Index Reports. 18. https://repository.upenn.edu/think_tanks/18

3 https://doi.org/10.47959/AJET.2021.1.1.1

(C) 2021 The Authors. Published by SRF. This is an open access article under the CC BY license (http://creativecommons.org/licenses/by/4.0/). 